Post refereed final draft of paper: Upson MA, Burgess PJ (2013). Soil organic carbon and root distribution in a temperate arable agroforestry system. Plant and Soil 373: 43-58.

DOI:10.1007/s11104-013-1733-x

\title{
Soil organic carbon and root distribution in a temperate arable agroforestry system
}

M.A. Upson \& P.J. Burgess ${ }^{1}$

Department of Environmental Science and Technology, Cranfield University, Cranfield, Bedfordshire, UK, MK43 OAL

${ }^{1}$ Corresponding author:

p.burgess@cranfield.ac.uk

Tel: +44 1234750111

Fax: +44 1234752971

Key words: agroforestry, roots, soil, carbon, carbon fractions, Populus,

carbon sequestration

\section{Abstract}

Aim: To determine, for arable land in a temperate area, the effect of tree establishment and intercropping treatments, on the distribution of roots and soil organic carbon to a depth of 1.5 $\mathrm{m}$.

Methods: A poplar (Populus sp.) silvoarable agroforestry experiment including arable controls was established on arable land in lowland England in 1992. The trees were intercropped with an arable rotation or bare fallow for the first 11 years, thereafter grass was allowed to establish. Coarse and fine root distributions (to depths of up to $1.5 \mathrm{~m}$ and up to $5 \mathrm{~m}$ from the trees) were measured in 1996, 2003, and 2011. The amount and type of soil carbon to $1.5 \mathrm{~m}$ depth was also measured in 2011.

Results: The trees, initially surrounded by arable crops rather than fallow, had a deeper coarse root distribution with less lateral expansion. In 2011, the combined length of tree and understorey vegetation roots was greater in the agroforestry treatments than the control, at depths below $0.9 \mathrm{~m}$. Between 0 and $1.5 \mathrm{~m}$ depth, the fine root carbon in the agroforestry treatment $\left(2.56 \mathrm{t} \mathrm{C} \mathrm{ha}^{-1}\right)$ was $79 \%$ greater than that in the control $\left(1.43 \mathrm{t} \mathrm{Cha}^{-1}\right)$. Although the soil organic carbon in the top $0.6 \mathrm{~m}$ under the trees $\left(161 \mathrm{t} \mathrm{C} \mathrm{ha}^{-1}\right)$ was greater than in the control (142 t C ha $\left.{ }^{-1}\right)$, a tendency for smaller soil carbon levels beneath the trees at lower depths, meant that there was no overall tree effect when a $1.5 \mathrm{~m}$ soil depth was considered. From a limited sample, there was no tree effect on the proportion of recalcitrant soil organic carbon.

Conclusions: The observed decline in soil carbon beneath the trees at soil depths greater than $60 \mathrm{~cm}$, if observed elsewhere, has important implication for assessments of the role of afforestation and agroforestry in sequestering carbon.

\section{Introduction}

Society is facing the challenge of how to increase food production, in the context of a rising world population, whilst also reducing greenhouse gas emissions. By 2020, the United Nations Environment Program (2011) has calculated that annual global greenhouse gas emissions need to decline from an anticipated $56 \mathrm{Gt} \mathrm{CO}_{2} \mathrm{e}$, under a business as usual scenario, to $44 \mathrm{Gt}_{\mathrm{CO}_{2}} \mathrm{e}$ to keep the mean global temperature increases beneath the target of $2^{\circ} \mathrm{C}$. It has been estimated that between 2.4 and $8.5 \mathrm{Gt} \mathrm{CO}_{2} \mathrm{e}$ of this reduction can be derived from changes in agricultural and forestry management. This includes "enhancing carbon sequestration by undertaking afforestation and agroforestry projects" (UNEP 2011). 
Agroforestry systems are of particular interest because they combine the potential to increase carbon sequestration (Pandey 2002; Montagnini 2004; Nair et al. 2009) whilst maintaining agricultural production. Although biomass accumulation aboveground is an obvious result of introducing trees into agricultural systems, the carbon stored is relatively labile (Janzen 2005), and dependent on the fate of the products derived from woody biomass. On the other hand, carbon accumulated in the soil can persist for millennia (Rumpel et al. 2002, Schöning and Kögel-Knabner 2006) and forms the largest terrestrial carbon pool (Batjes 1996).

The dominant pathway for carbon to enter the soil is through fine root turnover; which has been estimated to account for a third of global annual net primary productivity (Jackson et al. 1997). Agroforestry systems may be expected to increase soil carbon storage by increasing the depth to which roots are present in the system, by continually turning over fine roots throughout the year (albeit at a slower rate in the dormant season (Black et al. 1998)), and by the inclusion of recalcitrant compounds which slow the rate of mineralisation (Recous et al. 2008). Any consideration of changes in gravimetric soil organic carbon (SOC) must also take into account changes in soil bulk density which may occur as a result of different management regimes (Nair 2011).

Whilst there are several studies of temperate agroforestry systems, most consider soil carbon at depths of less than $0.5 \mathrm{~m}$ (Bambrick et al. 2010; Peichl et al. 2006; Oelbermann and Voroney, 2007; Gordon et al. 2006; Sharrow and Ismail 2004). In this study we attempt to quantify the impact of introducing trees into arable systems on the distribution of roots and soil organic carbon to a depth of $1.5 \mathrm{~m}$.

\section{Materials and Methods}

\section{Site description}

A poplar (Populus sp.) agroforestry experiment, described by Burgess et al. (2005), was established in 1992 on a level 4.5 ha arable field on the Cranfield University Experimental Station at Silsoe, Bedfordshire, England (lat. $52^{\circ} 0^{\prime} \mathrm{N}$, long. $0^{\circ} 26^{\prime} \mathrm{W}$; altitude: $60 \mathrm{~m}$ ). The soil (of the Holdenby series) is categorised as a clay to a depth of more than $1.5 \mathrm{~m}$, and a soil texture analysis shows a composition of $55 \%$ clay $(<2 \mu \mathrm{m}), 26 \%$ silt $(2-63 \mu \mathrm{m})$ and $19 \%$ sand $(63-200$ $\mu \mathrm{m}$ ) and some stones (Ashby 2001). Because of the clay mineralogy, the soil shows a marked level of swelling and shrinkage in response to wetting and drying. The mean annual rainfall (1992-2006) was about $630 \mathrm{~mm}$ whilst mean daily air temperature was $10.4^{\circ} \mathrm{C}$. Prior to the establishment of the agroforestry experiment, the whole site had been used for arable cropping for at least 20 years

The northern and eastern parts of the field were maintained as control areas. In the rest of the field, a 2.5 ha area of poplars was planted in April 1992 comprising three replicated blocks including each combination of four poplar hybrids and three agroforestry cropping treatments. The poplars were planted at an interval of $6.4 \mathrm{~m}$ along rows, aligned in an approximately north-south direction; each poplar hybrid planted as a contiguous group of five trees, with a guard tree (buffer) at the end of each row (Fig. 1). Rows were spaced $10 \mathrm{~m}$ apart, and comprised an uncultivated $2 \mathrm{~m}$ strip at the base of the trees and an $8 \mathrm{~m}$ wide strip that was ploughed each autumn. The poplars were planted as $1.5-2.0 \mathrm{~m}$ unrooted sets to a depth of $0.6 \mathrm{~m}$, into a $1.5 \mathrm{~m}$ wide polythene-film mulch extending along the tree rows; the edges were mechanically buried under the soil to leave an exposed strip of plastic 1-m-wide. This was maintained until the end of 1999, when the polythene was removed and a grass-clover treestrip was sown by hand. 


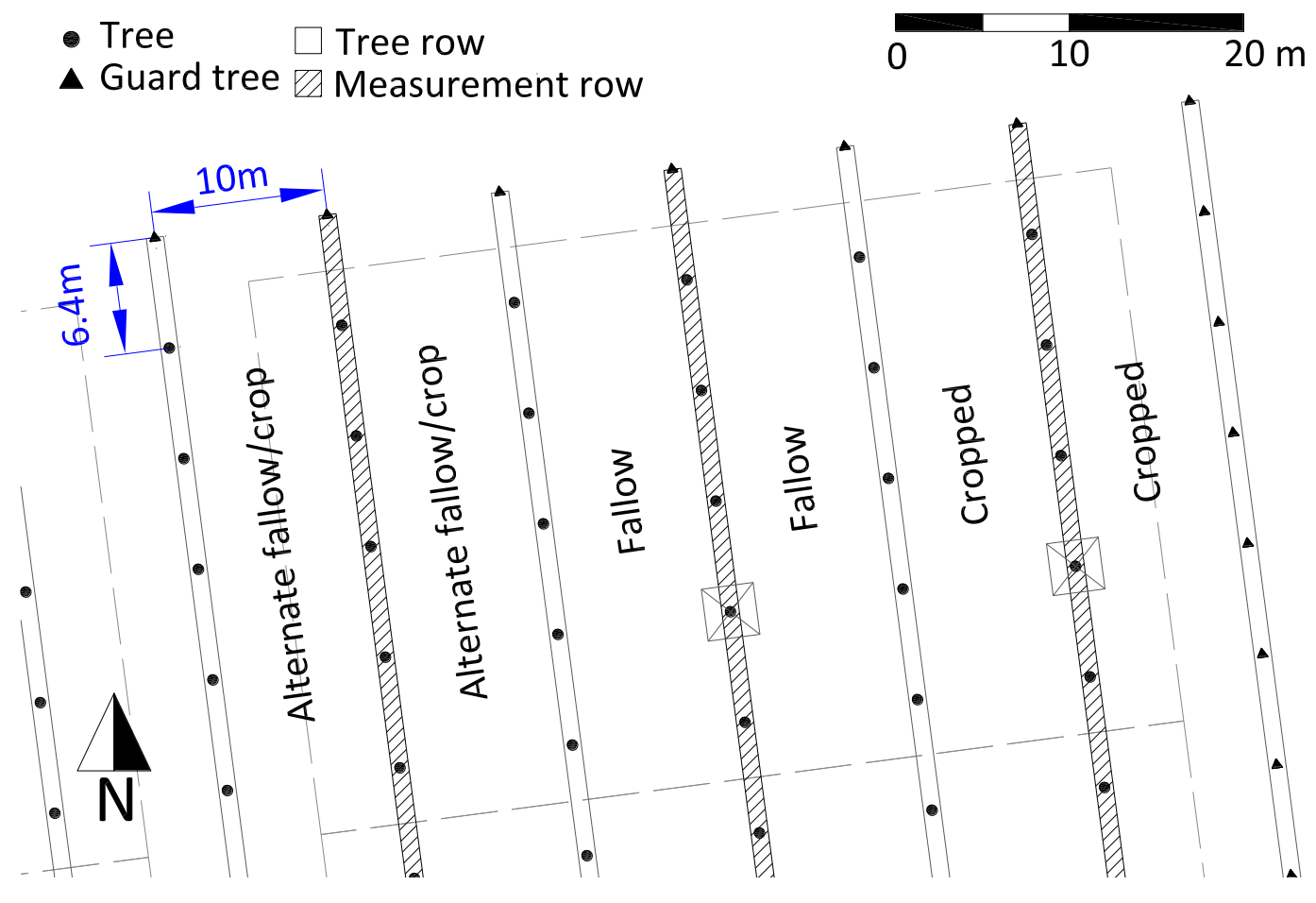

Fig. 1. Plan view of the Beaupre hybrid treatment (indicated by dashed line) within Block 1, containing three agroforestry treatments: cropped, fallow, and alternate crop/fallow. The rows of measurements trees are hatched, sampled trees are indicated by a cross-hatched box. The complete experiment consisted of three blocks comprising four poplar-hybrids and three agroforestry treatments, and three blocks to the north of trees comprising control areas. Only the fallow and cropped treatments within the Beaupré poplar-hybrid treatment and the control areas are considered in this study.

Each replicate block included three pairs of alleys each with a central measurement tree row. The alleys adjacent to these measurement rows were then allocated to three cropping treatments: i) "agroforestry-cropped", ii) "agroforestry-fallow" and iii) an alternating treatment, which is not considered further in this paper. From 1992 to 2003, the control areas and each of the alleys were ploughed on an annual basis. An arable crop was then established in the control and cropped agroforestry treatment, with the exception of 2001, when waterlogging meant that all treatments were maintained as a bare-fallow (Table 1). The arable crops were conventionally managed and harvested receiving fertiliser and agrochemicals as appropriate. The last arable crop (spring beans) was planted and harvested in 2003. From 2004 to 2011 all of the agroforestry and control areas remained uncultivated and a grass sward was allowed to establish naturally.

The poplars were pruned during the autumns of 1993, 1995, 1997, 1998 and 2000; with the aim of achieving a clear bole to a height of about $8 \mathrm{~m}$. Waste arising from pruning was removed from the experimental area. In June 2011, the Beaupré poplars had attained a mean diameter at $1.3 \mathrm{~m}$ of $36.2( \pm 0.5 \mathrm{SE}) \mathrm{cm}$ and $38.0( \pm 0.5 \mathrm{SE}) \mathrm{cm}$ in the cropped and fallow treatments respectively. Mean heights for these treatments were 24.6 ( $\pm 0.2 \mathrm{SE}) \mathrm{m}$ and 25.4 ( \pm $0.3 \mathrm{SE}) \mathrm{m}$ respectively. 
Table 1. Management of the cropped area in the "agroforestry-fallow", "agroforestry-cropped" and "control" areas a from 1992 to 2011b.

\begin{tabular}{lll}
\hline Year & Agroforestry-fallow & Agroforestry -cropped and control \\
\hline $1992-2003$ & Bare-earth fallow & Winter wheat (92), linseed (93), \\
& & spring wheat (94), winter wheat (95), winter wheat \\
& & $(96)$, winter wheat (97), winter beans (98), spring barley \\
& & $(99)$, winter wheat (00), bare fallow (01), winter barley \\
& & $(02)$, spring beans (03) \\
$2004-2011$ & Uncultivated - natural regeneration of a grass sward
\end{tabular}

${ }^{\mathrm{a}}$ The cropped and fallow agroforestry treatments comprised a row of trees bordered on either side by a $10 \mathrm{~m}$ alley. A $2 \mathrm{~m}$ strip, centred on the tree row remained uncultivated during the course of the experiment. The remaining 8-m of each alley was cultivated as shown.

${ }^{\mathrm{b}}$ From 1992 to 2003, each cultivated area was ploughed annually.

\section{Selection of sample trees}

All of the root and soil carbon measurements were centred on Beaupré, the largest of the four poplar hybrids (Burgess et al. 2005). It is produced from a cross of black cottonwood (Populus trichocarpa Torrey and A. Gray ex Hook) and eastern cottonwood (Populus deltoides Batram ex Marshall) from western and eastern North America respectively.

In 1996, four years after planting, the coarse root distribution perpendicular to the tree rows (i.e. into the alley) was determined for three Beaupré trees which were present in a row between the measurement rows (Fig 1). The alley on one side of each sample tree had been continuously cropped; the other maintained continuously fallow. In 2003, the coarse root distribution was measured from six trees in measurement rows (one cropped and one fallow in each of the three blocks) using a root trench (5.0 m long, $1.2 \mathrm{~m}$ deep and $1.0 \mathrm{~m}$ wide), perpendicular to the tree-row stretching into an alley. The process was repeated in 2011 on a different six trees to a depth of $1.5 \mathrm{~m}$.

\section{Coarse roots}

In 1996, 2003 and 2011, the number of coarse roots $(>2 \mathrm{~mm} \varnothing$ ) was counted within $0.2 \mathrm{~m}$ by $0.2 \mathrm{~m}$ grids along the length of the trench to a depth of up to $1.5 \mathrm{~m}$ (Bohm, 1979). This provided a measurement of coarse root density per $0.04 \mathrm{~m}^{2}$.

In order to make comparisons between coarse root distribution data recorded in 1996 and 2003 (Nkomaula 1996; Pasturel 2004), data from each of the three years were aggregated into similar depth increments and five increments of $1 \mathrm{~m}$ from the nearest tree $(0-5 \mathrm{~m})$. Because the coarse root count data were highly skewed and did not satisfy the assumption of normality; the 'Kruskal-Wallis' test (Conover 1971) implemented in the 'agricolae' package (de Mendiburu 2010) was used to make pair-wise comparisons of the count of roots found at each depth and distance for each year and treatment. Depth and distance were analysed separately for simplicity, and independently for each year. Note that in 1996, the measurements of the coarse roots in a cropped and fallow treatment were taken on the same tree, and therefore are not independent of each other.

\section{Fine roots}

Measurements of fine roots were taken in 2003 and 2011. In July 2003, undisturbed soil cores (of volume $207 \mathrm{~cm}^{3}$ ) were taken at distances of $0,1,2,3$, and $4 \mathrm{~m}$ from the base of six sample trees. At each distance, samples were taken at depths of 15, 45, 75, 105, and $135 \mathrm{~cm}$. Samples were suspended in 3 litres of water for 24 hours, then washed by hand and poured through a fine mesh sieve $(710 \mu \mathrm{m})$. In June 2011, a second set of undisturbed soil cores (of volume 146 $\mathrm{cm}^{3}$ ) were taken at the same distances and depths from six different sample trees, and at six 
control plots (with two at the same latitude of each block). The control plots were situated at least $20 \mathrm{~m}$ away from the nearest tree, and away from the field edge.

To release the fine roots, the core was separated into a plastic bottle (of $250 \mathrm{~cm}^{3}$ volume), filled with deionised water and placed inside an end-over-end agitator for at least 12 hours. Samples were emptied onto a sieve with an aperture size of $710 \mu \mathrm{m}$ and washed with water to remove the clay slurry.

In both years, roots were floated off from other debris, and the root length determined using the intersection method, described by Bohm (1979). It was not possible to separate tree roots from the roots of herbaceous plants in either year. After length determination, the root samples were dried at $105^{\circ} \mathrm{C}$ to a constant weight, and reweighed. Fine root mass and length density were determined by dividing total length and mass by the volume of the sample. The cumulative carbon with depth was calculated by taking the mean fine root mass density (mg $\mathrm{cm}^{-3}$ ) for each treatment at each depth and multiplying it by an assumed increment depth of $30 \mathrm{~cm}$ with each sampling point at its centre $(0-30,30-60,60-90,90-120$, and $120-50 \mathrm{~cm})$. The product was multiplied by the relative carbon content of fine roots as determined by dry combustion (44.47\%).

\section{Soil organic carbon and bulk density}

Detailed measurements of soil organic carbon and bulk density were made in 2011. Soil samples were taken at six depths $(5,15,30,50,83$, and $128 \mathrm{~cm})$ with the assumption that measurements taken at these points were representative of corresponding depth increments $(0-10,10-20,20-40,40-60,60-105$, and $105-150 \mathrm{~cm})$. Six samples were taken at five distances from each sampled tree $(0.5,1.5,2.5,3.5$ and $4.5 \mathrm{~m})$, perpendicular to the tree row. An associated bulk density sample was taken at each sampling point, following the methods of Klute (1986). Corresponding samples were also taken at the same depths from the same six control positions used for fine root length measurements. All 216 soil samples were analysed for gravimetric soil organic carbon using a modified Walkley-Black method (British Standards Institute 1990). In order to allow future comparisons with soil organic carbon contents derived from other techniques, 27 samples (9 samples from each treatment) were also analysed using a Vario EL III Elemental Analyser (Elementar Analysensysteme GmbH, Donaustrasse, Germany). The results from the elemental analyser were within $3 \%$ of the results from the titration method.

Volumetric soil organic carbon was calculated by multiplying gravimetric soil organic

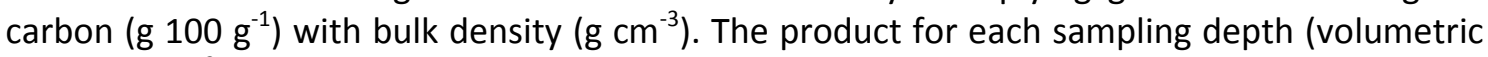
$\mathrm{SOC}$ in $\mathrm{g} \mathrm{cm}^{-3} \times$ depth increment size in $\mathrm{cm}$ ) was then summed to give cumulative volumetric soil organic carbon to each of six depths: 0-10, 0-20, 0-40, 0-60, 0-105 and 0-150 cm. Analysis was completed on each to examine the implications of sampling to different depths. The soil carbon stock was not measured at the time of tree establishment in 1992; however because the level field had been uniformly cultivated for the preceding 20 years, it was assumed that the soil carbon content across the field was uniform at time of planting.

\section{Fractionation of soil organic carbon}

The type of soil organic carbon was determined for 18 soil samples (drawn from the 27 retested with the elemental analyser) using the fractionation procedure outlined by Zimmermann et al. (2007). Nine samples each were taken from the control and the agroforestry-cropped treatment, from three depths $(5,30$, and $83 \mathrm{~cm})$. All agroforestry samples were taken at a distance of $2.5 \mathrm{~m}$ from the sample tree.

The procedure outlined by Zimmermann uses a combination of particle size, density, and chemical fractionation to isolate five soil organic carbon fractions. Each sample was passed through a $2 \mathrm{~mm}$ sieve, and then $30 \mathrm{~g}$ of soil was suspended in $150 \mathrm{ml}$ of water and disrupted with $22 \mathrm{~J} \mathrm{~cm}^{-3}$ to break up large aggregates. The sample was then passed through a series of filter papers. The portion greater than $63 \mu \mathrm{m}$ was stirred with sodium polytungstate and centrifuged to separate a light $\left(<1.8 \mathrm{~g} \mathrm{~cm}^{-3}\right)$ and a heavy fraction $\left(>1.8 \mathrm{~g} \mathrm{~cm}^{-3}\right)$. These two 
fractions were considered to be particulate organic matter (POM) and sand and stable aggregates $(S+A)$ respectively.

A filtrate $(<0.45 \mu \mathrm{m})$ of the portion $<63 \mu \mathrm{m}$ (suspended in water) was removed for the determination of dissolved organic carbon (DOC). The remaining $0.45 \mu \mathrm{m}<$ fraction $<63 \mu \mathrm{m}$ was taken to consist of silt and clay particles $(s+c)$; of this, a chemically resistant soil organic carbon fraction ( $\mathrm{rSOC}$ ) was determined by oxidation for 18 hours with sodium hypochlorite. Organic carbon content for each solid fraction was determined by dry combustion with an elemental analyser. DOC was determined by thermal oxidation with a liquid analyser. The relative percentage of total sample carbon was calculated by dividing soil organic carbon content within each fraction by sample soil organic carbon for the bulk soil.

\section{Statistical analysis}

Analysis of variance was completed using the statistical environment $R$, version 2.13.0 ( $R$ Development Core Team 2011). Gravimetric soil organic carbon, soil bulk density, volumetric soil organic carbon, and fine root length and mass density were tested using the 'aov' function. Treatment (control, agroforestry-cropped, agroforestry-fallow), distance, and depth were modelled as fixed effects, whilst block was included as a random effect. A further fixed effect (referred to as agroforestry $v$ control in results tables) into which treatment and distance were nested, and which differentiated between agroforestry and control was added to address the imbalance caused by the inclusion of distance into the model (since only one 'distance' was tested for each control plot).

Cumulative volumetric soil organic carbon was tested with fixed effects for treatment, crop and distance, and a random effect for block. This analysis was completed independently for each cumulative depth i.e. 0-10, 0-20, 0-40, 0-60, 0-105, and 0-150 cm. Model assumptions were checked using normality and residual plots, and where appropriate, transformations of the data were made. Multiple comparison tests were made using the least significance test function implemented in the package 'agricolae' (de Mendiburu 2010) utilising the Benjamini \& Hochberg procedure (1995), with an alpha level of 0.05 throughout.

\section{Results}

\section{Coarse root distribution}

The total of 1018 coarse roots, counted across the six trenches in 2011, was greater than the 858 roots counted in 2003 , and the 268 counted in 1996. Effects $(p<0.05)$ of treatment, depth, distance and distance $x$ depth interactions were found in each year.

At each distance or depth increment, the root counts in the agroforestry-fallow treatment were greater $(p<0.05)$ than or similar to those in the agroforestry-cropped treatment (Table 2). In addition within the agroforestry-fallow treatment, in each of the three years, the coarse-root count at a distance of 1-2 $\mathrm{m}$ from the tree was statistically similar $(p>0.05)$ to that in the tree row $(0-1 \mathrm{~m})$. By contrast, within the agroforestry-cropped treatment, the coarse-root count at a distance of $1-2 \mathrm{~m}$ was less $(p<0.05)$ than that in the tree row $(0-1 \mathrm{~m})$ in each of the three years.

Four years after planting the poplars, penetration of coarse roots into the continuouslycropped alley was minimal, but they extended to the middle of the alley ( $5 \mathrm{~m}$ from the tree) in the fallow treatment. Consequently root counts at distances between $1 \mathrm{~m}$ and $4 \mathrm{~m}$ were found to be significantly greater $(p<0.05)$ in the agroforestry-fallow treatment. With the exception of the most shallow $(0-20 \mathrm{~cm})$ and the penultimate depth $(60-80 \mathrm{~cm})$, the root counts in the fallow treatment were greater $(p<0.05)$ than in the continuously cropped treatment (Table 2).

In 2003 , there were only significantly $(p<0.05)$ more coarse roots in the fallow treatment than the cropped treatment at a distance of 2-3 m (Table 2). The fallow treatment also had more $(p<0.05)$ roots than the agroforestry-cropped treatment at a depth of $20-40 \mathrm{~cm}$. 
In 2011, following the end of annual cultivation in 2003 , the mean coarse root count in the fallow treatment was greater $(p<0.05)$ than that in the cropped treatment at distances of 1-2 $\mathrm{m}$ and 3-4 $\mathrm{m}$. The fallow treatment also had more $(\mathrm{p}<0.05)$ coarse roots than the cropped treatment at a depth of $60-80 \mathrm{~cm}$ (Table 2).

Table 2. Coarse root distribution measurements in 1996, 2003 and 2011: mean number of roots recorded across the three blocks (roots per $0.04 \mathrm{~m}^{2}$ ). Data have been summed across distance in increments of $1 \mathrm{~m}$, from five $0.2 \mathrm{~m} \times 0.2 \mathrm{~m}$ for each $1 \mathrm{~m}$ section. Values greater than 1 per $0.04 \mathrm{~m}^{2}$ have been shaded. Only data recorded to a depth of $1 \mathrm{~m}$ were included in statistical analyses $(n=3)$. Results of the Kruskal-Wallis test have been included for depth and distance for each year. Note that depth and distance were analysed independently, as was each year; hence results from these tests are not comparable between years.

\begin{tabular}{|c|c|c|c|c|c|c|c|c|c|c|c|c|}
\hline \multirow{3}{*}{$\begin{array}{l}\text { Year and } \\
\text { depth }(\mathrm{cm})\end{array}$} & & \multicolumn{11}{|c|}{ Agroforestry treatment and distance $(\mathrm{m})$} \\
\hline & & \multicolumn{5}{|c|}{ Agroforestry-fallow } & & \multicolumn{5}{|c|}{ Agroforestry-cropped } \\
\hline & & $0-1$ & $1-2$ & $2-3$ & $3-4$ & 4-5 & & $0-1$ & $1-2$ & $2-3$ & $3-4$ & 4-5 \\
\hline 1996 & & a & $a b c$ & $\mathrm{bc}$ & c & $d$ & & $a b$ & $\mathrm{~d}$ & $d$ & $d$ & $d$ \\
\hline $0-20$ & bc & 3.7 & 0.6 & 0.1 & 0.0 & 0.0 & bc & 1.7 & 0.0 & 0.0 & 0.0 & 0.0 \\
\hline $20-40$ & a & 3.0 & 0.8 & 0.9 & 1.3 & 0.0 & bc & 1.7 & 0.1 & 0.0 & 0.0 & 0.0 \\
\hline $40-60$ & a & 1.9 & 1.3 & 0.3 & 0.3 & 0.1 & bc & 4.6 & 0.0 & 0.0 & 0.0 & 0.0 \\
\hline $60-80$ & $a b$ & 1.4 & 0.7 & 1.0 & 0.6 & 0.0 & bc & 1.7 & 0.1 & 0.0 & 0.0 & 0.0 \\
\hline $80-100$ & $a b$ & 0.2 & 0.2 & 1.2 & 0.2 & 0.0 & c & 0.1 & 0.0 & 0.0 & 0.0 & 0.0 \\
\hline 2003 & & kl & kl & $\mathrm{Im}$ & $\mathrm{mn}$ & no & & k & $\mathrm{Im}$ & no & no & 0 \\
\hline $0-20$ & $\mathrm{mn}$ & 2.2 & 2.2 & 1.1 & 0.4 & 0.2 & $\mathrm{n}$ & 3.2 & 0.7 & 0.4 & 0.2 & 0.1 \\
\hline $20-40$ & $\mathrm{k}$ & 3.5 & 4.7 & 2.9 & 1.5 & 1.3 & Imn & 3.3 & 1.8 & 1.2 & 0.5 & 0.3 \\
\hline $40-60$ & $\mathrm{kl}$ & 2.7 & 2.4 & 1.8 & 1.6 & 0.7 & $\mathrm{klm}$ & 3.5 & 2.1 & 0.8 & 0.9 & 0.7 \\
\hline $60-80$ & Imn & 1.9 & 2.5 & 1.1 & 1.1 & 0.3 & Imn & 3.2 & 1.5 & 0.7 & 0.5 & 0.3 \\
\hline $80-100$ & $m n$ & 1.2 & 1.2 & 0.6 & 0.2 & 0.5 & Imn & 2.8 & 1.2 & 0.8 & 0.6 & 0.4 \\
\hline $100-120$ & & 1.0 & 1.3 & 0.3 & 0.2 & 0.1 & & 1.2 & 1.2 & 0.4 & 0.3 & 0.0 \\
\hline 2011 & & v & vw & $x y$ & $w x$ & $x y$ & & v & $x y$ & $w x$ & $y$ & $y$ \\
\hline $0-20$ & $w x$ & 1.5 & 2.8 & 1.8 & 2.4 & 1.8 & $w x$ & 2.4 & 2.2 & 2.8 & 1.3 & 1.1 \\
\hline $20-40$ & v & 3.2 & 4.5 & 3.0 & 3.2 & 2.1 & vw & 4.3 & 2.4 & 3.1 & 1.2 & 1.9 \\
\hline $40-60$ & $w x$ & 4.2 & 2.4 & 1.4 & 1.4 & 0.4 & $w x$ & 4.0 & 1.3 & 1.3 & 1.1 & 1.0 \\
\hline $60-80$ & $x y$ & 3.1 & 1.6 & 1.1 & 0.8 & 0.5 & z & 2.3 & 0.4 & 0.8 & 0.1 & 0.2 \\
\hline $80-100$ & $y z$ & 1.2 & 1.3 & 0.5 & 0.5 & 0.4 & $z$ & 1.0 & 0.5 & 0.5 & 0.5 & 0.0 \\
\hline $100-120$ & & 1.0 & 0.7 & 0.2 & 0.2 & 0.2 & & 0.7 & 0.4 & 0.1 & 0.2 & 0.0 \\
\hline $120-140$ & & 1.2 & 0.4 & 0.1 & 0.4 & 0.1 & & 0.3 & 0.2 & 0.2 & 0.2 & 0.4 \\
\hline $140-150$ & & 0.8 & 0.2 & 0.1 & 0.0 & 0.1 & & 0.3 & 0.1 & 0.0 & 0.3 & 0.0 \\
\hline
\end{tabular}

Non-significant differences ( $p>0.05$ ) between depth and distance means, within a given year, are indicated by a common letter. 


\section{Fine root distribution and carbon}

Although the number of fine roots is expected to increase as the trees increase in size, the use of an agitator in 2011 to release roots trapped in the soil is likely to have increased the recovery of very fine roots. For this reason, and the fact that no arable control was sampled in 2003 , fine root length data from these two years have been analysed independently.

In 2003, no difference $(p=0.277)$ was found between the fine root length of the agroforestry-fallow and agroforestry-cropped treatments, however there were effects of distance $(p<0.001)$ and depth $(p<0.001)$ for the agroforestry treatments as a whole (note, root counts were not made in the arable control in this year, Table 3a). The mean fine root length decreased $(p<0.05)$ from $1.22 \mathrm{~cm} \mathrm{~cm}^{-3}$ at a depth of $0-30 \mathrm{~cm}$ to $0.37 \mathrm{~cm} \mathrm{~cm}^{-3}$ at a depth of 150 $\mathrm{cm}$ (Table 4). The mean fine root length density to a depth of $150 \mathrm{~cm}$ declined $(p<0.05)$ from $0.93 \mathrm{~cm} \mathrm{~cm}^{-3}$ below the grass sward directly beneath the tree, to $0.31 \mathrm{~cm} \mathrm{~cm}^{-3}$ in the centre of the alley.

Table 3. Effects of depth, agroforestry-cropping treatment, distance and interactions on the length and mass density of fine roots in a) 2003 and b) 2011. In 2011, the effects included a comparison of the control with the agroforestry treatments.

\begin{tabular}{lrcc}
\hline a) Effects in 2003 & df & $\begin{array}{l}\text { P values for } \\
\text { fine root length }\end{array}$ & $\begin{array}{c}\text { P values for } \\
\text { fine root mass }\end{array}$ \\
\hline Depth & 4 & $<0.001$ & $<0.001$ \\
Treatment & 1 & 0.277 & 0.776 \\
Distance & 4 & $<0.001$ & $<0.001$ \\
Treatment $\times$ distance & 4 & 0.097 & 0.049 \\
Treatment $\times$ depth & 4 & 0.707 & 0.694 \\
Distance $\times$ depth & 16 & 0.786 & 0.984 \\
\hline Residual & 114 & & \\
& & & \\
\hline b) Effects in 2011 & df & P values for & P values for \\
& & fine root length & fine root mass \\
\hline Agroforestry v Control & 1 & 0.019 & $<0.001$ \\
Depth & 4 & $<0.001$ & $<0.001$ \\
Treatment & 1 & 0.453 & 0.936 \\
Distance & 4 & 0.060 & 0.023 \\
Agroforestry v Control $\times$ depth & 4 & $<0.001$ & 0.421 \\
Treatment $\times$ distance & 4 & 0.144 & 0.209 \\
Treatment $\times$ depth & 4 & 0.385 & 0.214 \\
Distance $\times$ depth & 16 & 0.140 & 0.691 \\
\hline Residual & 139 & & \\
\hline
\end{tabular}

The data recorded in 2011 indicate significantly greater fine root length density in the agroforestry treatments $(p<0.05)$, and an effect of depth $(p<0.001)$ which varied between the agroforestry treatment and the control $(p<0.001$, Table $3 b)$. The mean fine root density in the cropped and fallow agroforestry treatments were similar $(p=0.45)$. As in 2003 , fine root length density declined with depth, but whilst fine root length density in the arable control and the agroforestry treatment were similar $(p>0.05)$ to a depth of $90 \mathrm{~cm}$, a greater $(p<0.05)$ length density was found in the agroforestry treatment at depths of $90-120 \mathrm{~cm}$ and $120-150 \mathrm{~cm}$ (Fig. 2). 


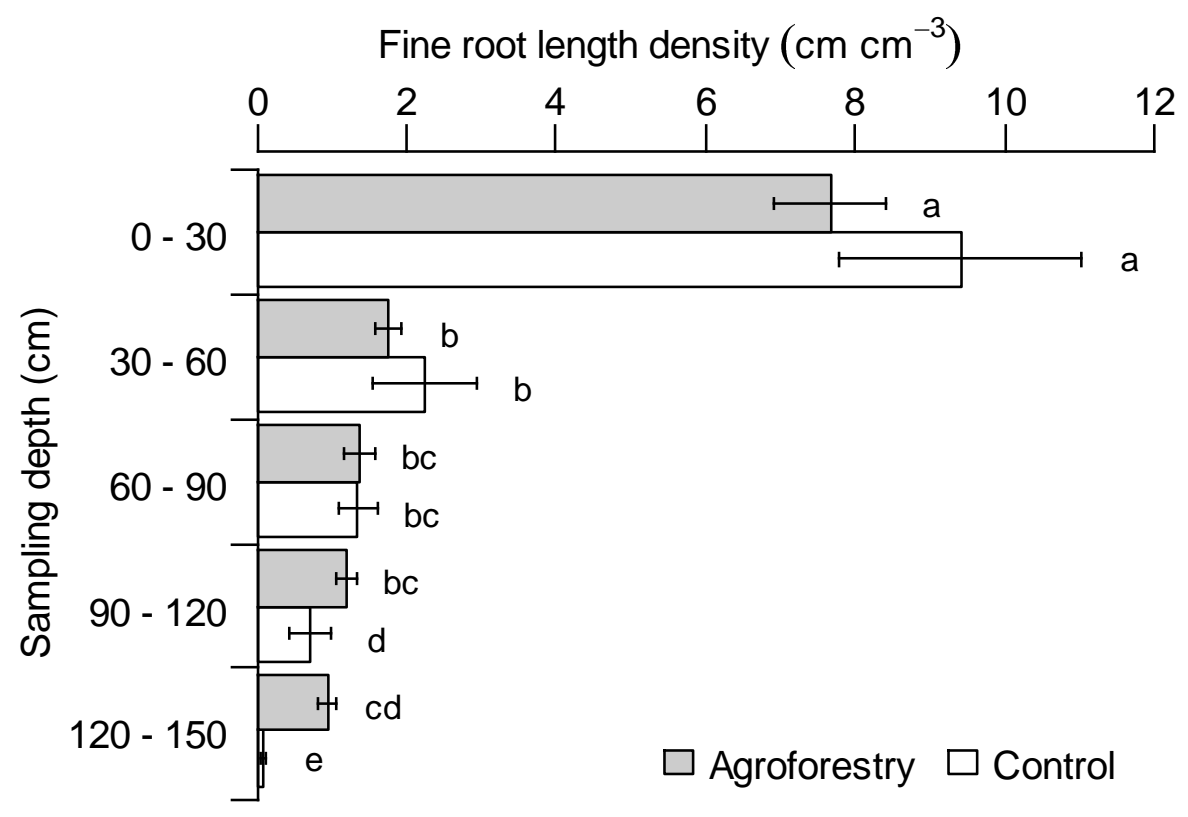

Fig. 2. Mean fine root length density from 2011 at each depth for the agroforestry and arable control. Bars with the same letter indicate a non-significant difference $(p=0.05)$. Error bars indicate standard error of the mean (control: $n=6$, agroforestry: $n=30$ ).

Although fine root length is often the focus of studies of water and nutrient uptake, fine root mass density is of interest in studies of carbon sequestration. In 2003, fine root mass showed similar trends to fine root length, with significant effects of depth $(p<0.001)$ and distance $(p<0.001$, Table $3 a)$. Fine root mass was significantly greater $(p<0.05)$ in the first 30 $\mathrm{cm}$ than all subsequent depths, whilst the fine root mass in the tree row $(0-1 \mathrm{~m})$ was greater $(p<0.05)$ than that at distances between $2 \mathrm{~m}$ and $5 \mathrm{~m}$ within the arable alley (Table 4). In 2011, the fine root mass also declined significantly $(p<0.001)$ with depth, ranging from $0.97 \mathrm{~g} \mathrm{~cm}^{-3}$ in the top $30 \mathrm{~cm}$ of soil, to $0.11 \mathrm{~g} \mathrm{~cm}^{-3}$ at a depth of $120-150 \mathrm{~cm}$ (Tables $3 \mathrm{~b}$ and $4 \mathrm{~b}$ ). The mass of fine roots at a distance of 3-4 $\mathrm{m}$ was less than for other distances $\left(0.38-0.45 \mathrm{~g} \mathrm{~cm}^{-3}\right.$, Table $\left.4 \mathrm{~b}\right)$

The quantity of carbon contained in the fine roots in each depth increment to $150 \mathrm{~cm}$ was calculated by multiplying the mean fine root mass for each treatment by the depth of the sampling increments and the carbon content. This showed that the cumulative carbon associated with fine roots, to a depth of $1.5 \mathrm{~m}$, in the agroforestry treatments $(2.56-2.58 \mathrm{t} \mathrm{C}$ $\left.\mathrm{ha}^{-1}\right)$ was $80 \%$ greater $(p<0.05)$ than in the control $\left(1.43 \mathrm{t} \mathrm{C} \mathrm{ha}^{-1}\right.$, Fig. 3$)$.

The specific root length was determined by dividing the fine root length by the corresponding fine root mass. The specific root length in the agroforestry-cropped $\left(69 \mathrm{~m} \mathrm{~g}^{-1}\right)$ and agroforestry-fallow $\left(60 \mathrm{~m} \mathrm{~g}^{-1}\right)$ treatments were less $(p<0.05)$ than that $\left(175 \mathrm{~m} \mathrm{~g}^{-1}\right)$ in the control, probably due to the presence of heavier lignified tree roots. 
Table 4. Effect of depth and distance on the fine root length density and the fine root mass density in a) 2003 and b) 2011. The measurements in 2011 include the control area. Mean \pm standard errors of the means, and number of replicates ( $n)$, with results from multiple comparison tests shown in superscript: means with the same letter are not significantly different. Note, test results are not comparable across year and distance/depth. Multiple comparison tests were not completed for fine root length and distance in 2011 as analysis of variance did not find this relationship significant.

\begin{tabular}{|c|c|c|c|c|c|c|}
\hline \multirow{2}{*}{$\begin{array}{l}\text { a) } 2003 \\
\text { Depth } \\
\text { (cm) }\end{array}$} & \multicolumn{3}{|c|}{$\begin{array}{l}\text { Fine root length } \\
\text { density }\left(\mathrm{cm} \mathrm{cm}^{-3}\right)\end{array}$} & \multicolumn{2}{|c|}{$\begin{array}{l}\text { Fine root mass } \\
\text { density }\left(\mathrm{g} \mathrm{cm}^{-3}\right)\end{array}$} & \multirow{2}{*}{$\begin{array}{l}\mathrm{n} \\
30\end{array}$} \\
\hline & $0-30$ & $1.22^{\mathrm{a}}$ & \pm 0.19 & $0.13^{\mathrm{a}}$ & \pm 0.02 & \\
\hline & $30-60$ & $0.56^{\mathrm{b}}$ & \pm 0.09 & $0.04^{b}$ & \pm 0.01 & 30 \\
\hline & $60-90$ & $0.41^{b}$ & \pm 0.05 & $0.04^{b}$ & \pm 0.01 & 30 \\
\hline & $90-120$ & $0.40^{b}$ & \pm 0.05 & $0.04^{b}$ & \pm 0.01 & 30 \\
\hline & $120-150$ & $0.37^{\mathrm{b}}$ & \pm 0.04 & $0.03^{b}$ & \pm 0.01 & 30 \\
\hline \multirow[t]{5}{*}{$\begin{array}{l}\text { Distance } \\
(\mathrm{m})\end{array}$} & $0-1$ & $0.93^{\mathrm{a}}$ & \pm 0.17 & $0.09^{\mathrm{a}}$ & \pm 0.02 & 30 \\
\hline & $1-2$ & $0.82^{\mathrm{a}}$ & \pm 0.14 & $0.08^{\mathrm{ab}}$ & \pm 0.02 & 30 \\
\hline & $2-3$ & $0.49^{b}$ & \pm 0.06 & $0.05^{b c}$ & \pm 0.01 & 30 \\
\hline & $3-4$ & $0.42^{b c}$ & \pm 0.06 & $0.05^{c d}$ & \pm 0.01 & 30 \\
\hline & $4-5$ & $0.31^{c}$ & \pm 0.03 & $0.03^{d}$ & \pm 0.01 & 30 \\
\hline \multicolumn{2}{|l|}{ a) 2011} & \multicolumn{2}{|c|}{$\begin{array}{l}\text { Fine root length } \\
\text { density }\left(\mathrm{cm} \mathrm{cm}^{-3}\right)\end{array}$} & \multicolumn{2}{|c|}{$\begin{array}{l}\text { Fine root mass } \\
\text { density }\left(\mathrm{g} \mathrm{cm}^{-3}\right)\end{array}$} & $\mathrm{n}$ \\
\hline \multirow[t]{5}{*}{$\begin{array}{l}\text { Depth } \\
\text { (cm) }\end{array}$} & $0-30$ & $7.95^{\mathrm{a}}$ & \pm 0.67 & $0.97^{a}$ & \pm 0.06 & 36 \\
\hline & $30-60$ & $1.84^{\mathrm{b}}$ & \pm 0.18 & $0.31^{b}$ & \pm 0.04 & 36 \\
\hline & $60-90$ & $1.37^{c}$ & \pm 0.17 & $0.20^{c}$ & \pm 0.03 & 36 \\
\hline & $90-120$ & $1.11^{\mathrm{c}}$ & \pm 0.13 & $0.20^{c}$ & \pm 0.04 & 36 \\
\hline & $120-150$ & $0.80^{d}$ & \pm 0.12 & $0.11^{d}$ & \pm 0.02 & 36 \\
\hline \multirow[t]{6}{*}{$\begin{array}{l}\text { Distance } \\
(\mathrm{m})\end{array}$} & $0-1$ & 2.37 & \pm 0.38 & $0.45^{a}$ & \pm 0.08 & 30 \\
\hline & $1-2$ & 2.95 & \pm 0.62 & $0.43^{a}$ & \pm 0.07 & 30 \\
\hline & $2-3$ & 1.98 & \pm 0.42 & $0.38^{\mathrm{a}}$ & \pm 0.07 & 30 \\
\hline & $3-4$ & 2.56 & \pm 0.67 & $0.27^{b}$ & \pm 0.05 & 30 \\
\hline & $4-5$ & 3.06 & \pm 0.76 & $0.39^{a}$ & \pm 0.08 & 30 \\
\hline & Control & 2.76 & \pm 0.71 & $0.45^{a}$ & \pm 0.08 & 30 \\
\hline
\end{tabular}




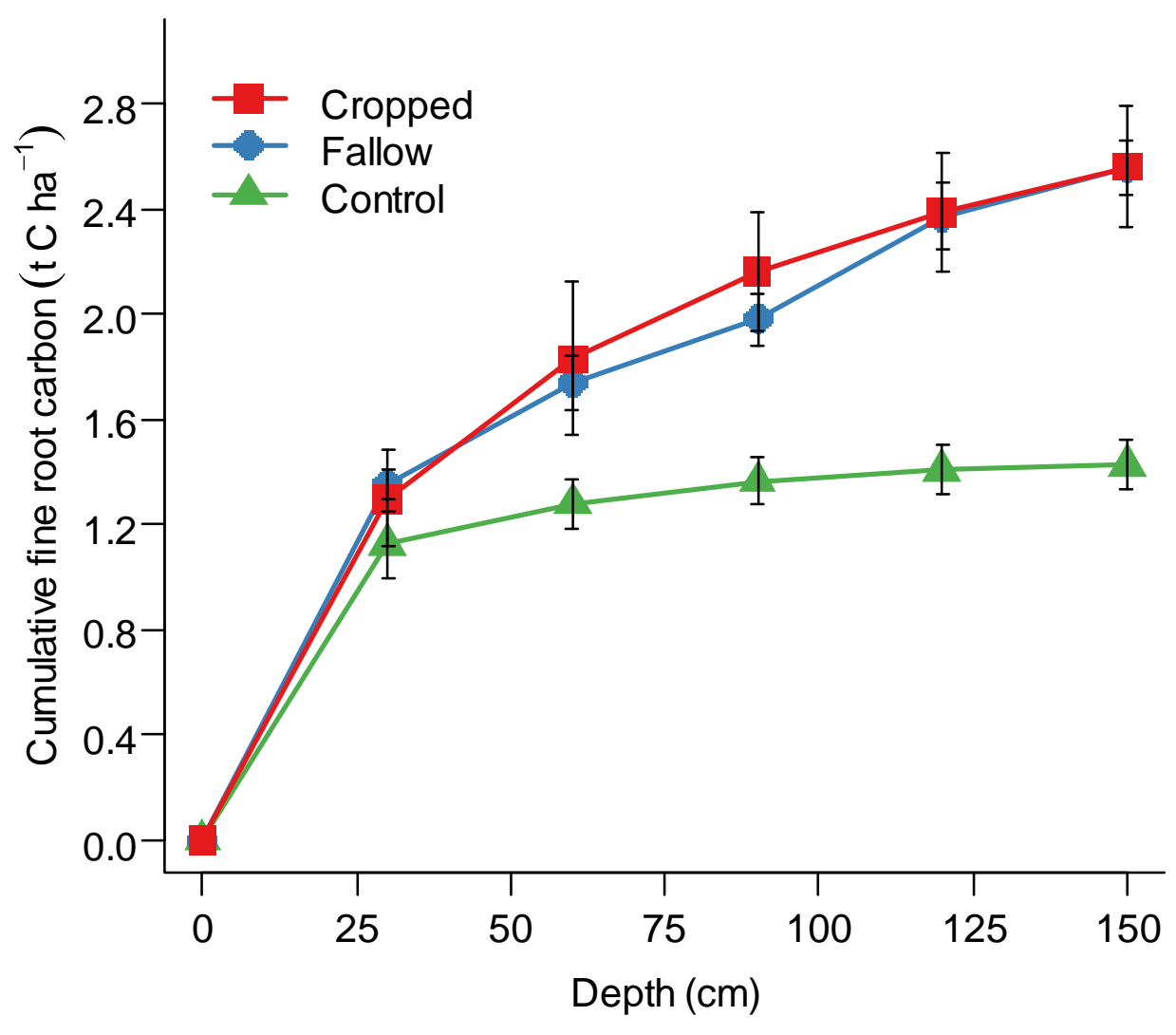

Fig. 3. Cumulative fine root carbon content of the control, agroforestry-fallow, and agroforestry-cropped treatment with depth. Error bars indicate standard error of the means (fallow: $n=15$, cropped: $n=15$, control: $n=6$ ).

\section{Soil bulk density}

In 2011, the soil bulk density was greater $(p<0.001)$ in the agroforestry plots than the control, this effect varied with depth $(p<0.001)$ (Table 5). At a depth of $0-40 \mathrm{~cm}$ the bulk densities of the control $\left(1.22 \mathrm{~g} \mathrm{~m}^{-3}\right)$ and agroforestry treatments $\left(1.28 \mathrm{~g} \mathrm{~cm}^{-3}\right)$ were similar (Fig. 4). However, at depths of 40-60, 60-105, and 105-150 cm, the bulk densities in the control (1.32, 1.30 and $1.15 \mathrm{~g} \mathrm{~cm}^{-3}$ ) were less than those in the agroforestry $\left(1.44,1.45\right.$ and $\left.1.42 \mathrm{~g} \mathrm{~cm}^{-3}\right)$. There was no difference $(p=0.19)$ in the bulk density of the agroforestry- fallow and agroforestry-cropped treatments. 


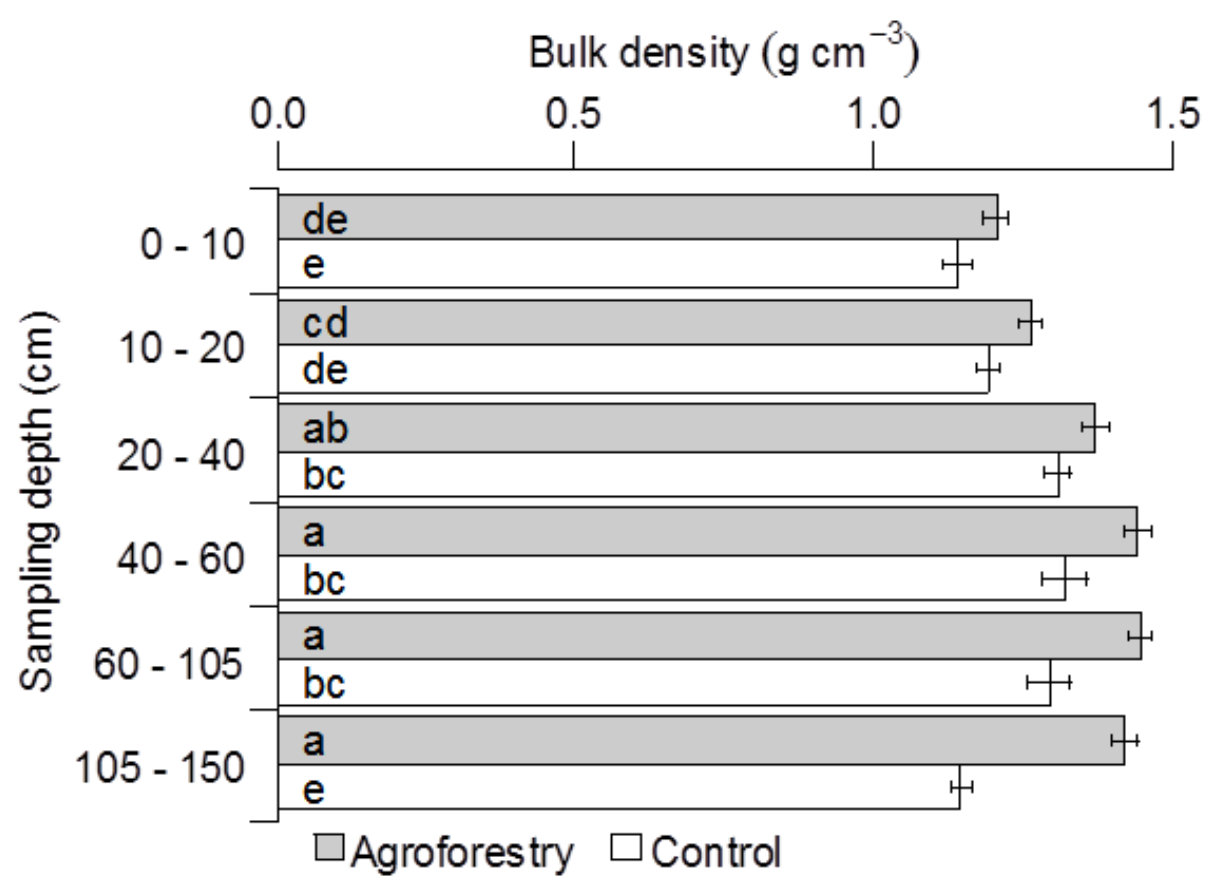

Fig. 4. Mean bulk density at depth for the agroforestry plots and the arable control. Bars with the same letter indicate no significant difference $(p=0.05)$. Error bars indicate standard error of the mean (control: $n=6$, agroforestry: $n=30$ ).

When considered to a depth of $150 \mathrm{~cm}$, there was no effect $(p=0.34)$ of distance from tree on the mean bulk density in the agroforestry plots (Table 5). However there was a distance effect for the top $40 \mathrm{~cm}(p<0.01$, Fig 5$)$. Within the top $40 \mathrm{~cm}$, soil bulk density increased $(p<0.01)$ towards the centre of the alley, and was greater $(p<0.05)$ at $2-5 \mathrm{~m}(1.30-$ $\left.1.33 \mathrm{~g} \mathrm{~cm}^{-3}\right)$ than the tree row $\left(1.23 \mathrm{~g} \mathrm{~cm}^{-3}\right)$ and the arable control $\left(1.22 \mathrm{~g} \mathrm{~cm}^{-3}\right.$, Fig. 6). As with the complete depth profile, the mean soil bulk density $(0-40 \mathrm{~cm})$ for the agroforestry treatments $\left(1.28 \mathrm{~g} \mathrm{~cm}^{-3}\right)$ was higher $(p<0.05)$ than the arable control $\left(1.22 \mathrm{~g} \mathrm{~cm}^{-3}\right)$.

Table 5: Analysis of the effects of depth, agroforestry cropping teratment, distance, and interactions thereof on soil bulk density, gravimetric and volumetric soil organic carbon (SOC) in 2011. Note that the analysis includes a factor differentiating the agroforestry from the control.

\begin{tabular}{lrrrr}
\hline Effect & df & $\begin{array}{l}\text { P value for } \\
\text { bulk density }\end{array}$ & $\begin{array}{l}\text { P value for } \\
\text { gravimetric } \\
\text { SOC }\end{array}$ & $\begin{array}{l}\text { P value for } \\
\text { volumetric } \\
\text { SOC }\end{array}$ \\
\hline Agroforestry v Control & 1 & $<0.001$ & 0.541 & 0.051 \\
Depth & 5 & $<0.001$ & $<0.001$ & $<0.001$ \\
Treatment & 1 & 0.187 & 0.436 & 0.534 \\
Distance & 4 & 0.344 & 0.013 & 0.146 \\
Agroforestry v Control $\times$ depth & 5 & 0.003 & 0.040 & 0.020 \\
Treatment $\times$ distance & 4 & 0.914 & 0.044 & 0.047 \\
Treatment $\times$ depth & 5 & 0.224 & 0.094 & 0.120 \\
Distance $\times$ depth & 20 & 0.256 & 0.541 & 0.818 \\
\hline Residuals & 168 & & & \\
\hline
\end{tabular}




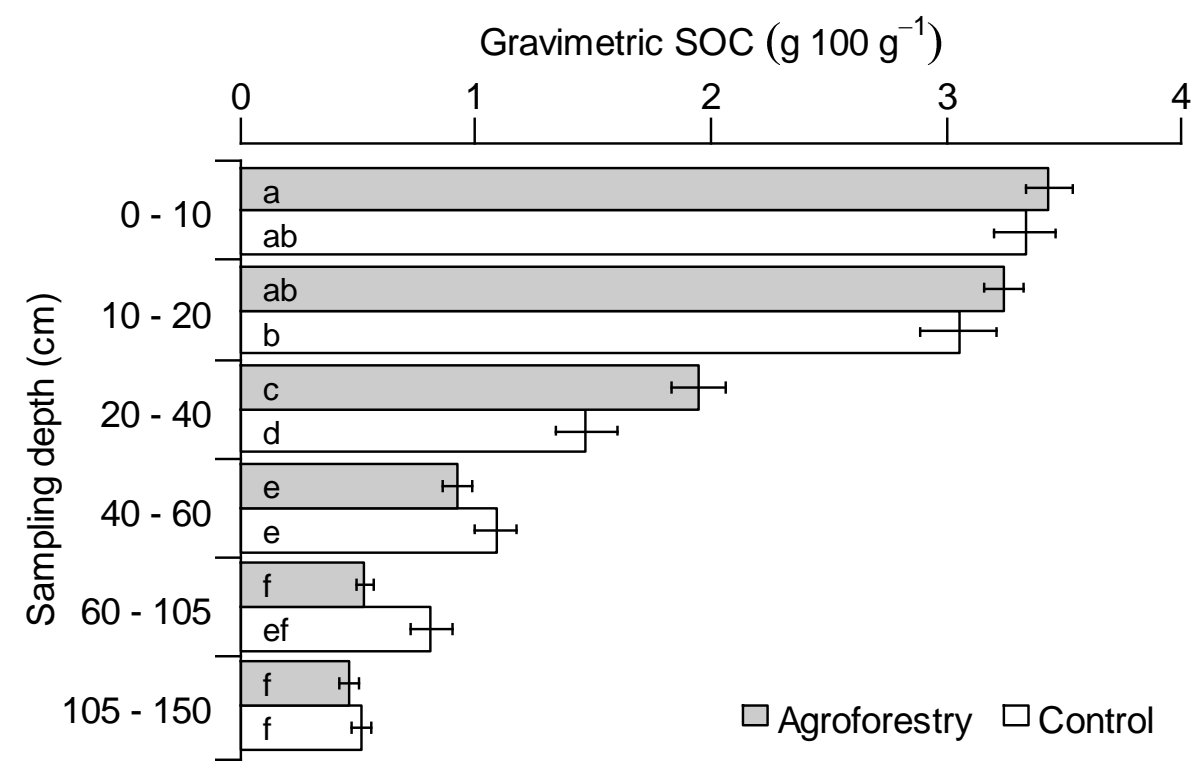

Fig. 5. Mean gravimetric soil organic carbon $(\mathrm{SOC})$ for the agroforestry plot and the arable control at each depth. Error bars indicate standard error of the mean. Bars with the same letter indicate no significant difference ( $p=0.05$, control: $n=6$, agroforestry: $n=30)$.

\section{Gravimetric soil organic carbon}

In 2011, the gravimetric soil organic carbon varied with depth $(<0.001)$ and this relationship differed $(p<0.05)$ between the arable and the agroforestry plots (Table 5$)$. Distance from the tree also had an effect $(p<0.05)$, which varied with agroforestry cropping treatment $(p<0.05)$. Although the gravimetric soil organic carbon was similar in the arable control and the agroforestry treatments at a depth of 0-20 cm (Fig. 5); at 20-40 cm, it was greater in the

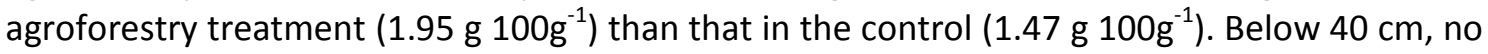
difference was found between treatments.

Mean gravimetric soil organic carbon was found to be greater $(p<0.05)$ under the tree

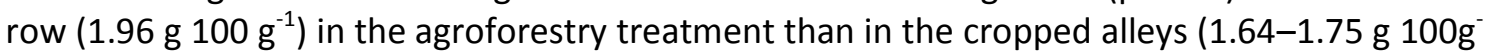
$\left.{ }^{1}\right)$, or the arable control (1.71 g $100 \mathrm{~g}^{-1}$, Table 6). This difference was associated with particularly high levels of gravimetric soil organic carbon in the tree row in the cropped

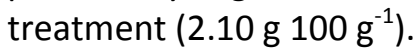

Table 6. Results of multiple comparison tests on the effect of distance on soil bulk density ( $\mathrm{g}$

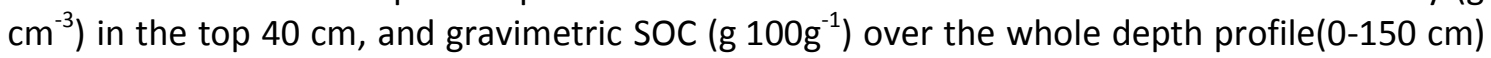
in 2011: mean, standard error of the mean and replication (n). Means with the same letter indicate no significant difference.

\begin{tabular}{rcccccc}
\hline \multicolumn{5}{c}{ Bulk Density $\left(\mathrm{g} \mathrm{cm}^{3}\right)$} & \multicolumn{4}{c}{ Gravimetric SOC $\left({\left.\mathrm{g} 100 \mathrm{~g}^{-1}\right)}\right.$} \\
& Mean & SE & $\mathrm{n}$ & Mean & SE & $\mathrm{n}$ \\
\hline Agroforestry & & & & & & \\
$0-1 \mathrm{~m}$ & $1.23^{\mathrm{c}}$ & 0.04 & 18 & $1.96^{\mathrm{a}}$ & 0.2 & 36 \\
$1-2 \mathrm{~m}$ & $1.25^{\mathrm{bc}}$ & 0.03 & 18 & $1.72^{\mathrm{b}}$ & 0.2 & 36 \\
$2-3 \mathrm{~m}$ & $1.30^{\mathrm{ab}}$ & 0.03 & 18 & $1.71^{\mathrm{b}}$ & 0.2 & 36 \\
$3-4 \mathrm{~m}$ & $1.30^{\mathrm{ab}}$ & 0.03 & 18 & $1.75^{\mathrm{b}}$ & 0.2 & 36 \\
$4-5 \mathrm{~m}$ & $1.33^{\mathrm{a}}$ & 0.03 & 18 & $1.64^{\mathrm{b}}$ & 0.2 & 36 \\
Control & $1.22^{\mathrm{c}}$ & 0.02 & 18 & $1.71^{\mathrm{b}}$ & 0.2 & 36 \\
\hline
\end{tabular}




\section{Volumetric soil organic carbon}

The volumetric soil organic carbon within the $20-40 \mathrm{~cm}$ depth increment was greater $(p<0.05)$ under the trees than that in the control area (Table 7). This meant that volumetric soil organic carbon was greater in the agroforestry plot when considered cumulatively for the $0-40 \mathrm{~cm}$ $(p<0.01)$ and $0-60 \mathrm{~cm}$ increments $(p<0.05$, Table 8). However a tendency for smaller carbon levels under the trees below $40 \mathrm{~cm}$, meant that the cumulative volumetric soil organic carbon to a depth of $1.5 \mathrm{~m}$ was not different $(\mathrm{p}=0.44)$ between the agroforestry $\left(224 \mathrm{t} \mathrm{Cha}^{-1}\right)$ and the control (215 t C ha ${ }^{-1}$ ) treatments (Table 8, Fig. 6). Whilst significant interactions between distance from tree and cropping treatment were found at cumulative depth increments of 0 40, 0-60, and 0-105 cm (Table 8), no obvious patterns emerged during multiple comparison testing.

Table 7. Results of multiple comparison tests on the effect of depth on volumetric $\mathrm{SOC}\left(\mathrm{g} \mathrm{cm}^{-3}\right)$ in 2011: mean, standard error of the mean and replication (n). Means with the same letter indicate no significant difference. Note that comparisons should only be made across treatments at the same depth increment, as the size of these increments varies.

\begin{tabular}{lllllll}
\hline & \multicolumn{3}{c}{ Agroforestry } & \multicolumn{3}{c}{ Control } \\
\hline Depth $(\mathrm{cm})$ & mean & SE & $\mathrm{n}$ & mean & SE & $\mathrm{n}$ \\
\hline $0-10$ & $4.12^{\mathrm{a}}$ & 0.12 & 30 & $3.82^{\mathrm{ab}}$ & 0.20 & 6 \\
$10-20$ & $4.07^{\mathrm{ab}}$ & 0.09 & 30 & $3.65^{\mathrm{b}}$ & 0.22 & 6 \\
$20-40$ & $2.66^{\mathrm{c}}$ & 0.15 & 30 & $1.92^{\mathrm{d}}$ & 0.17 & 6 \\
$40-60$ & $1.31^{\mathrm{e}}$ & 0.08 & 30 & $1.43^{\mathrm{e}}$ & 0.11 & 6 \\
$60-105$ & $0.75^{\mathrm{fg}}$ & 0.05 & 30 & $1.05^{\mathrm{ef}}$ & 0.12 & 6 \\
$105-150$ & $0.65^{\mathrm{fg}}$ & 0.06 & 30 & $0.59^{\mathrm{g}}$ & 0.05 & 6 \\
\hline
\end{tabular}

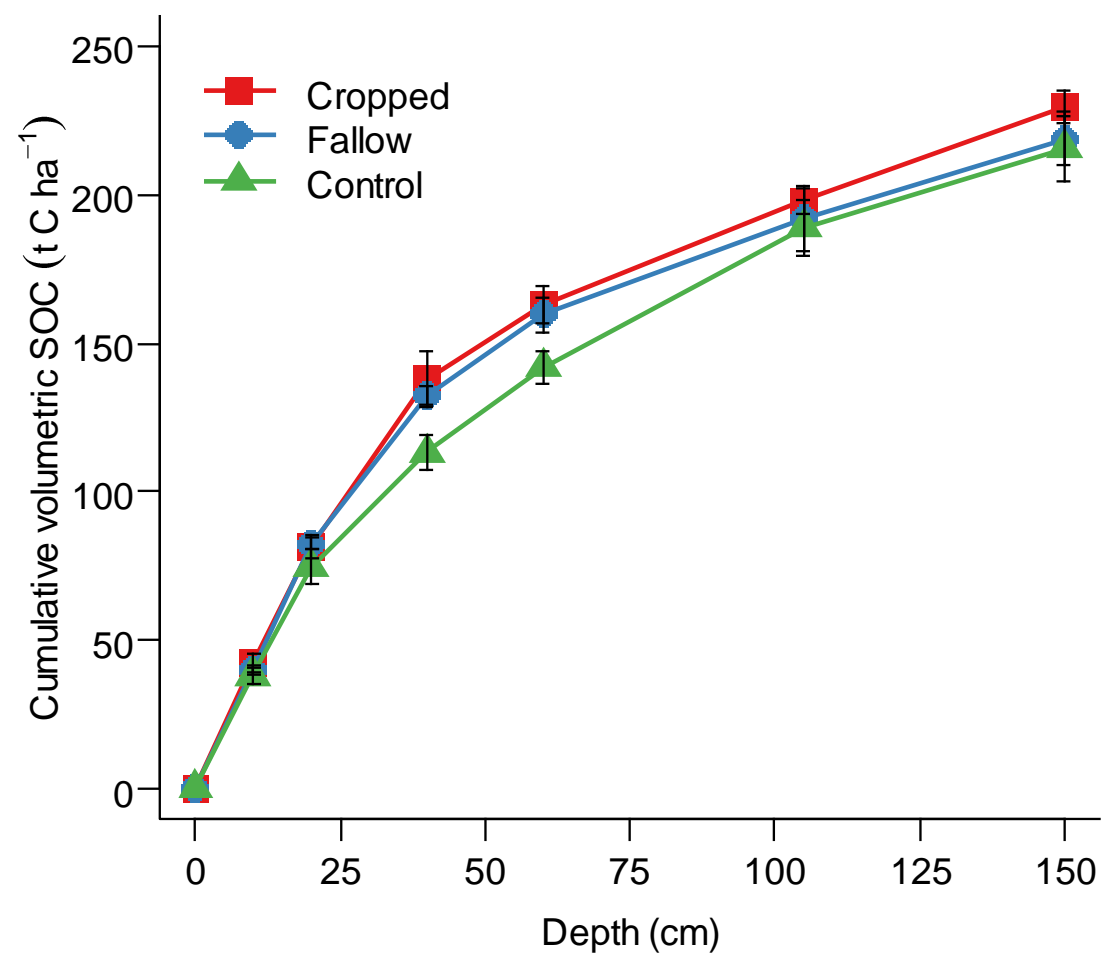

Fig. 6. Cumulative soil organic carbon for each treatment, calculated by multiplying each volumetric soil organic carbon measurement by the depth of each assumed sampling increment ( $\mathrm{C} \mathrm{Cha}{ }^{-1}$ to the appropriate depth). Error bars indicate standard error of the mean (fallow: $n=15$, cropped: $n=15$, control: $n=6$ ). 
Table 8. Significance (to two significant figures) of the effects of the control, distance from tree, the agroforestry treatment and interaction on the volumetric soil organic carbon for six cumulative depths $(\mathrm{cm})$ - each column represents a separate ANOVA.

\begin{tabular}{lrrllllr}
\hline Effect & \multicolumn{1}{c}{$\mathrm{df}$} & \multicolumn{7}{c}{ P-value } \\
\cline { 2 - 8 } & & $0-10$ & $0-20$ & $0-40$ & $0-60$ & $0-105$ & $0-150$ \\
\hline Agroforestry v Control & 1 & 0.28 & 0.079 & 0.004 & 0.026 & 0.57 & 0.44 \\
Distance & 4 & 0.90 & 0.70 & 0.20 & 0.085 & 0.28 & 0.38 \\
Treatment & 1 & 0.28 & 0.73 & 0.34 & 0.60 & 0.49 & 0.24 \\
Treatment $\times$ distance & 4 & 0.20 & 0.44 & 0.023 & 0.022 & 0.048 & 0.22 \\
Residuals & 23 & & & & & & \\
\hline
\end{tabular}

\section{Soil carbon fractions}

The proportion of the soil organic carbon that was found in the chemically resistant fraction ( $r S O C)$ did not change with depth $(p=0.36)$ or with treatment $(p=0.47)$, or the interaction of the two $(p=0.46)$. However there were effects of depth on the proportion of the most labile forms of soil carbon: dissolved organic carbon $(p<0.05)$ and particulate organic matter $(p<0.001)$. Similarly high levels of dissolved organic carbon (DOC) were found at 5 and $30 \mathrm{~cm}$, but a lower proportion was found at $83 \mathrm{~cm}$ than $30 \mathrm{~cm}$. In a similar way, more particulate organic matter (POM) was found in top $5 \mathrm{~cm}$ than at 30 and $83 \mathrm{~cm}$ (Table 9).

The agroforestry treatment had a lower overall $(p<0.01)$ proportion of the carbon sorbed on sand and stable aggregates $(S+A)$. There were depth $\times$ treatment interactions $(p<0.05)$ for this fraction, but no consistent pattern.

Table 9. Mean fraction of total sample organic carbon (\%) in the 'agroforestry-cropped' treatment and arable control for fractions isolated using Zimmermann's (2007) methods. These are dissolved organic carbon (DOC), particulate organic matter (POM), carbon sorbed on sand and stable aggregates $(S+A)$, silt and clay $(s+c)$, and chemically resistant soil organic carbon $(\mathrm{rSOC})$. Significant differences $(\mathrm{p}<0.05)$ for each isolated fraction are indicated by different letters $\mathrm{rSOC}$ and $\mathrm{s}+\mathrm{c}$ were not tested with multiple comparison tests as effects were not found to be significant in the analysis of variance. One outlier was removed at $83 \mathrm{~cm}$ in the agroforestry treatment for the $\mathrm{rSOC}$ and $\mathrm{s}+\mathrm{c}$ fractions, in all other cases $\mathrm{n}=3$.

\begin{tabular}{lcccccc}
\hline Treatment & Depth $(\mathrm{cm})$ & DOC & POM & S + A & S + c & rSOC \\
\hline Agroforestry- & 5 & $0.98^{\mathrm{ab}}$ & $5.52^{\mathrm{c}}$ & $40.1^{\mathrm{f}}$ & 42.6 & 10.8 \\
cropped & 30 & $1.05^{\mathrm{a}}$ & $2.04^{\mathrm{d}}$ & $26.6^{\mathrm{fg}}$ & 58.0 & 12.2 \\
& 83 & $0.63^{\mathrm{b}}$ & $2.50^{\mathrm{d}}$ & $24.1^{\mathrm{g}}$ & 54.6 & 8.4 \\
Control & & & & & & \\
& 5 & $0.76^{\mathrm{ab}}$ & $7.18^{\mathrm{c}}$ & $40.3^{\mathrm{f}}$ & 39.6 & 12.2 \\
& 30 & $1.00^{\mathrm{a}}$ & $1.92^{\mathrm{d}}$ & $32.8^{\mathrm{fg}}$ & 54.2 & 10.0 \\
& 83 & $0.54^{\mathrm{b}}$ & $1.73^{\mathrm{d}}$ & $56.0^{\mathrm{e}}$ & 30.9 & 10.9 \\
\hline
\end{tabular}




\section{Discussion}

\section{Coarse roots}

Our results indicate that during the first four years after tree establishment, competition from arable crops and cultivation of the soil altered the distribution of the tree roots (Table 2). Measurements of soil water content, reported by Burgess et al. $(1996 ; 1997)$, suggest that the primary reason for the poor colonisation of tree roots in the cropped alleys was water competition. Generally the arable crop, established in the preceding autumn, was able to develop an extensive root system to extract substantial quantities of water before the leaves of the deciduous poplar had reached maximum area (Burgess et al., 2005). This competition from the arable crop restricted lateral extension in the first few years after establishment, and confined a large part of tree root development to the tree row.

By eleven years (2003), the cumulative growth of the tree meant that it had become more competitive, however the roots of trees surrounded by the cropped alleys continued to show a more restricted distribution than those previously surrounded by fallow. Mulia and Dupraz (2006) found a similar distribution of fine tree roots with depth within a 7-9 year-old poplar-agroforestry experiment in southern France. Nineteen years after planting (2011), and following the development of a naturally regenerating grass sward from 2003, the cessation of annual cultivation meant that the tree roots could colonise the surface layers. However, at least in the fallow treatment, the greatest concentration of roots continued to occur at a depth of $20-40 \mathrm{~cm}$, perhaps as a result of competition from the perennial grass crop.

\section{Fine roots}

Unfortunately, unlike other studies (Mulia and Dupraz, 2006), we were unable to distinguish between the fine roots of the grass understorey and the poplars. Between 2003, when a grass understorey was allowed to establish in each treatment, and 2011, the mean fine root length density in the top $30 \mathrm{~cm}$ of soil increased from $1.2 \mathrm{~cm} \mathrm{~cm}^{-3}$ to $7-8 \mathrm{~cm} \mathrm{~cm}^{-3}$. The lack of a difference between the agroforestry and the control at this depth indicates a high presence of grass roots. The fine root density of $7-8 \mathrm{~cm} \mathrm{~cm}^{-3}$ lies between relatively low values of $2 \mathrm{~cm} \mathrm{~cm}^{-}$ ${ }^{3}$ for grassland within a Dehesa agroforestry system of oak and grass in Spain (Moreno et al. 2005), and $10-15 \mathrm{~cm} \mathrm{~cm}^{-3}$ for ryegrass in Norway (Pietola and Alakukku 2005).

Between a soil depth of $90 \mathrm{~cm}$ and the deepest sample at $150 \mathrm{~cm}$, the fine root length density in the agroforestry treatments was greater than in the control (Fig. 2), suggesting a high proportion of fine tree roots. The presence of fine tree roots is certainly indicated by the presence of tree coarse roots at this depth.

The specific root length for trees can be a magnitude lower than that for grass. Guo et al. (2007) reported in Australia, that specific root length ranged from $8.5 \mathrm{~m} \mathrm{~g}^{-1}$ for a pine plantation to $56 \mathrm{~m} \mathrm{~g}^{-1}$ for grassland. Data presented by Pietola and Alakukku (2005) suggest a specific root length of ryegrass of $269 \mathrm{~m} \mathrm{~g}^{-1}$. The values in the current study $\left(59-161 \mathrm{~m} \mathrm{~g}^{-1}\right)$ are within the above range of values for a mix of tree and herbaceous roots.

Although the total length of tree fine roots may be relatively small compared to grass roots, the mass of tree fine roots can be important when considering fine root carbon. In fact, there was a greater total mass of fine roots under the trees, particularly when measurements were taken below a depth of $30 \mathrm{~cm}$, as about half of the fine root carbon in the agroforestry treatments occurred below this depth (Fig. 3). Overall, measured fine root $C$ was found to contribute just $1.1-1.2$ and $0.7 \%$ of the total soil organic carbon of the agroforestry treatments and the non-tree control respectively.

\section{Bulk density}

The soil bulk density was generally greater in the agroforestry plots than the arable control. A more detailed analysis of the top $40 \mathrm{~cm}$ of soil demonstrates that greater bulk density in the agroforestry plot tended to occur in the centre of the cultivated part of the alleys (Table 6). 
This contrasts with other studies (Messing et al., 1997; Seobi et al., 2005) which suggest that bulk density under afforested land and agroforestry systems tend to be lower than arable systems. The high bulk density in the agroforestry-fallow could have been caused by compaction during the regular mechanical cultivation. Data collected by Aves (2002) also identified compaction under the tramlines in the cropped alleys which, unlike the control area, remained in the same place each year. In addition there was some additional machinery use associated with tree pruning and yield measurements.

Bukhari et al. (1998) found, in a cracking clay in central Sudan, that soil bulk density was greater under a forestry treatment than an abandoned farm. They attribute increased bulk density beneath trees to both compression of the soil exerted by root growth, and lower soil moisture content caused by increased water uptake by trees. Whilst the former is unlikely, the latter effect may have occurred at this site, where the soil is also a cracking clay. Certainly the soil was visually observed to be drier under the trees than in the arable control during sampling.

\section{Soil depth and soil organic carbon}

Although this experiment did not measure fine root turnover, it was assumed that increased fine root turnover due to the presence of the trees would increase soil organic matter. The measurement of the different soil fractions in both the agroforestry-cropped and the control treatments certainly indicates that the proportion of labile carbon was greatest at shallow depths $(5$ and $30 \mathrm{~cm})$, coinciding with the greatest levels of fine roots in both treatments and coarse roots in the agroforestry treatment.

Within the top $20 \mathrm{~cm}$, there was no significant effect of the trees on the soil carbon content. This could partly be explained by the ploughing that occurred to this approximate depth for each of the first 11 years of the experiment, and the associated disaggregation and mineralisation of organo-mineral complexes. By contrast, between 20 and $40 \mathrm{~cm}$, the

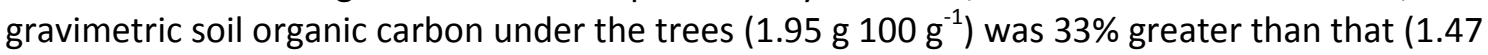
$\mathrm{g} 100 \mathrm{~g}^{-1}$ ) in the arable control. This corresponds to the depth with the greatest quantity of coarse roots. Had the coarse roots been included in the soil carbon measurement, the total carbon content (soil + plant) within the soil at this depth increment would be even higher.

Similar results have been found with another 19 year old poplar based agroforestry experiment in Canada. Gordon et al. (2006) report that within the top $5 \mathrm{~cm}$, the gravimetric soil organic carbon $\left(2.3{\left.\mathrm{~g} 100 \mathrm{~g}^{-1}\right) \text { in an agroforestry system with } 111 \text { trees ha }}^{-1}\right.$ was similar to that $\left(2.2 \mathrm{~g} \mathrm{flog}^{-1}\right)$ in the arable control. However a study at the same site to a greater depth of

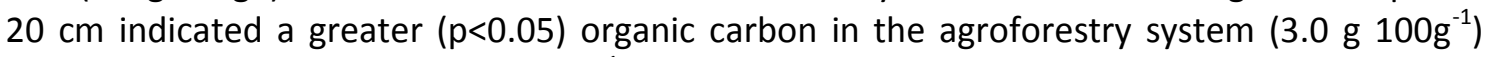

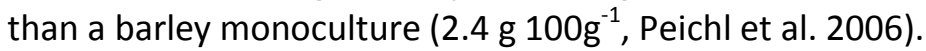

Below $90 \mathrm{~cm}$, the fine root length density in the agroforestry plot was greater $(p<0.05)$ than the arable control; however, there was not an increase in gravimetric or volumetric soil organic carbon. In fact, there was a tendency for less soil organic carbon to be detected in the agroforestry treatment beneath $60 \mathrm{~cm}$. This fact is illustrated by the lack of difference in cumulative volumetric $S O C$ below $60 \mathrm{~cm}$ ( $p>0.05$, Table 8). These results imply that sampling to a depth of $20 \mathrm{~cm}$ would indicate no effect of the trees, sampling to $60 \mathrm{~cm}$ would indicate a benefit from trees, and sampling to $150 \mathrm{~cm}$ would again suggest no effect.

One explanation for the apparent declining SOC levels at depth beneath the trees is a bulk density effect. This can be discounted however, as the higher bulk densities recorded in the agroforestry treatments (Fig. 4) would lead to greater rather than smaller volumetric SOC. A second explanation is that the difference is a result of pre-experimental soil heterogeneity; perhaps the soil at this particular depth in the agroforestry plot has always had a lower level of soil carbon. Unfortunately we do not have data to indicate if this was or was not the case. However it is worth noting that other studies have also demonstrated that establishing trees on arable land can lead to declines in soil carbon at depth. Vesterdal and Ritter (2002) report that in a 30 year study of afforestation of former arable land in Denmark, the soil carbon 
content increased at 0-5 cm, whilst there was a decrease at $15-25 \mathrm{~cm}$. Jug et al (1999) in a study of short-rotation poplar plantations on arable land in Germany, also showed that the cessation of ploughing led to a tendency for soil carbon to decline at $30 \mathrm{~cm}$. These two results may be explained by the cessation of ploughing which had formerly incorporated surface organic matter at depth. However in a 40 year study of forest re-establishment on former agricultural land in South Carolina in the USA, Richter et al. (1999) found that there was a significant increase in soil organic carbon in the top $7.5 \mathrm{~cm}$ of soil, but a significant decline between depths of 35 and $60 \mathrm{~cm}$. Richter et al (1999) proposed that the decline may be caused by the slow oxidation of previous organic matter associated with crops. It is also possible that increased water use by the trees could have resulted in greater soil aeration at depth and consequently greater respiration rates (Moore and Knowles 1989). Certainly the soil in the control plots was visually wetter than the soil under the trees.

An alternative explanation is the 'priming effect'; where inputs of readily accessible carbon from root exudates and root deposition leads to a change in the composition of microbial and fungal communities towards those which favour decomposition of older, recalcitrant forms of soil carbon (Fontaine et al. 2007, 2011). Observing this effect, Carney et al (2007), found in a free air carbon enrichment experiment, that $52 \%$ of aboveground gains in carbon storage were offset by 'priming effect' induced carbon losses in the top 0-10 cm of soil, in scrub oak in Florida.

In the present study, there was insufficient replication of soil fractionation measurements to demonstrate whether the proportion of recalcitrant soil carbon ( $\mathrm{rSOC}$ ) at a depth of $83 \mathrm{~cm}$ under the trees $(8.4 \%)$ was significantly lower than that under the control (10.9\%). In fact, statistical analysis showed no treatment or depth effect on the proportion of chemically resistant soil organic carbon, 19 years after tree establishment.

\section{Rates of change in soil organic carbon}

Assuming that soil carbon over a depth of $1.5 \mathrm{~m}$ was similar in 1992, the non-significant difference in the soil carbon contents of the agroforestry and control treatments of $8.7 \mathrm{t} \mathrm{Cha}{ }^{-1}$ after 19 years (Fig. 6), would be equivalent to an annual change of $0.46 \mathrm{t} \mathrm{C} \mathrm{ha}^{-1}$. However this non-significant change masks significant differences at individual depths. For example the annual rate would be equivalent to a gain of $0.77 \mathrm{t} \mathrm{C} \mathrm{ha}{ }^{1}$ at $20-40 \mathrm{~cm}$, and a loss of $0.70 \mathrm{t} \mathrm{Cha}{ }^{-1}$ at $60-105 \mathrm{~cm}$. Post and Kwon (2000) cite average annual changes of soil carbon from eight studies, following a change from agriculture to forestry in cool temperate regions, that range from a loss of $0.04 \mathrm{t} \mathrm{Cha}^{-1}$ to a gain of $0.66 \mathrm{t} \mathrm{Cha}^{-1}$. For a 21-year-old poplar silvoarable system (111 trees ha ${ }^{-1}$ ) in Ontario, Canada, the mean annual soil carbon sequestration rate in the top $30 \mathrm{~cm}$ of a sandy loam soil was $0.30 \mathrm{t} \mathrm{Cha}^{-1} \mathrm{a}^{-1}$ (Bambrick et al. 2010). The greater change in the surface layer at the Silsoe site may be due to the higher tree density (156 rather than 111 trees $\mathrm{ha}^{-1}$ ). In addition, the clay at the Silsoe site may be better suited to the accumulation of organic matter than the sandy-loam found at the Canadian site (Veen and Ladd, 1985).

\section{Conclusions}

This study affirms many of the methodological issues recently levelled against studies of carbon sequestration in agroforestry systems (Nair 2011). Chief among these is the question of depth: our results demonstrate that to get an accurate picture of the carbon sequestration potential of temperate agroforestry systems, soil sampling needs to be conducted to a greater depth than is routinely practiced. In this study, $64 \%$ and $41 \%$ of the total soil carbon detected was found below 20 and $40 \mathrm{~cm}$ respectively (relative to $1.5 \mathrm{~m}$ ). This literal lack of depth in research is peculiar to temperate systems; Nair et al. (2009) cites seven studies of soil carbon in tropical agroforestry systems that conducted sampling to a depth of a metre or more - one at $2 \mathrm{~m}$.

Whilst temperate agroforestry systems undoubtedly store more carbon aboveground compared to conventional agricultural systems, the impact of tree planting on soil carbon at 
depth is important. Whilst this study indicates that poplar based agroforestry systems may accumulate soil carbon rapidly at shallow depths; they may also be responsible for a rapid loss of soil carbon deeper in the soil profile. Possible reasons for this are soil drying leading to oxidation, and the priming effect of new accessible carbon. Further study is needed to establish if this is a general effect which can be generalised over a range of sites.

\section{Acknowledgements}

The authors gratefully acknowledge the support of William Stephens in securing funding for the research and the help of Francois Clavagnier, Pascal Pasturel, and Julius Nkomaula in undertaking important fieldwork. The fractionation of the soil organic carbon was undertaken by Andy Gregory at Rothamsted Research. We also acknowledge support from Forest Research and the Scottish Forestry Trust during the writing up of this work.

\section{References}

Ashby Z (2001) Effect of soil characteristics on poplar growth. Unpublished BSc thesis. Cranfield University, Bedfordshire.

Aves C (2002) Factors influencing cereal establishment in a silvoarable system. Unpublished BSc thesis. Cranfield University, Bedfordshire.

Bambrick AD, Whalen JK, Bradley RL, Cogliastro A, Gordon AM, Olivier A, Thevathasan NV (2010) Spatial heterogeneity of soil organic carbon in tree-based intercropping systems in Quebec and Ontario, Canada. Agrofor. Syst. 79: 343-353

Batjes NH (1996) Total carbon and nitrogen in the soils of the world. Europ. J. Soil Sci. 47: 151163

Benjamini $Y$, Hochberg $Y$ (1995). Controlling the false discovery rate: a practical and powerful approach to multiple testing. J. R Stat. Soc. 57(1): 289-300

Black KE, Harbron CG, Franklin M, Atkinson D, Hooker JE (1998) Differences in root longevity of some tree species. Tree Physiol. 18: 259-264

Bohm W (1979) Methods of Studying Root Systems. Springer-Verlag, Heidelberg.

British Standards Institute (1990) BS 1377-3: 1990 Methods of test for: Soils for civil engineering purposes - Part 3: Chemical and electro-chemical tests.

Bukhari $Y$ (1998) Tree-root influence on soil physical conditions, seedling establishment and natural thinning of Acacia seyal var. seyal on clays of Central Sudan. Agrofor. Syst. 4: 3343

Burgess PJ, Stephens W, Anderson G, Durston, J (1996) Water use by a poplar -wheat agroforestry system. Vegetation Management in Forestry, Amenity and Conservation Areas: Managing for Multiple Objectives. Asp. Appl. Biol. 44: 129-136

Burgess PJ, Nkomaula JC, Medeiros Ramos AL (1997) Root distribution and water use in a fouryear old silvoarable system. Agrofor. Forum 8(3): 15-18

Burgess PJ, Incoll LD, Corry DT, Beaton A, Hart BJ (2005) Poplar (Populus spp) growth and crop yields in a silvoarable experiment at three lowland sites in England. Agrofor. Syst. 63: 157-169

Carney KM, Hungate BA, Drake, BG, Megonigal, JP (2007). Altered soil microbial community at elevated $\mathrm{CO}_{2}$ leads to loss of soil carbon. Proc. Natl. Acad. Sci. U. S. A. 104: 4990-5.

Conover WJ (1971) Practical Nonparametric Statistics. John Wiley \& Sons Inc, New York.

de Mendiburu F (2010) Agricolae: Statistical Procedures for Agricultural Research. R package version 1.0-9.

Fontaine S, Barot S, Barré P, Bdioui N, Mary B, Rumpel C. (2007) Stability of organic carbon in deep soil layers controlled by fresh carbon supply. Nature. 450: 277-80.

Fontaine S, Henault C, Aamor A., Bdioui N., Bloor JMG., Maire V, Mary B, Revaillot S, Maron PA (2011) Fungi mediate long term sequestration of carbon and nitrogen in soil through their priming effect. Soil Biol. Biochem. 43: 86-96 
Gordon AM, Naresh RPF, Thevathasan V (2006) How much carbon can be stored in Canadian agroecosystems using a silvopastoral approach? In: Mosquera-Losada MR, McAdam JH (eds.). Silvopastoralism and Sustainable Land Management: Proceedings of an International Congress on Silvopastoralism and Sustainable Management Held in Lugo Spain, in April 2004. CABI Publishing, pp. 210-218

Guo, LB, Wang, M, Gifford, RM (2007) The change of soil carbon stocks and fine root dynamics after land use change from a native pasture to a pine plantation. Plant Soil. 299: 251262

Jackson RB, Mooney HA, Schulze ED (1997) A global budget for fine root biomass, surface area, and nutrient contents. Proc. Natl. Acad. Sci. U. S. A. 94: 7362-7366

Janzen HH (2005). Soil carbon: A measure of ecosystem response in a changing world? Can. J. Soil Sci. 85: 467-480

Jug, Makeschin F, Rehfuess K, Hofmann-Schielle C (1999) Short-rotation plantations of balsam poplars, aspen and willows on former arable land in the Federal Republic of Germany. III. Soil ecological effects. For. Ecol. Manag. 121: 85-99

Klute A (1986) Methods of Soil Analysis: Part 1 - Physical and Mineralogical Methods. 2nd Ed. American Society of Agronomy, Wisconsin.Messing I, Alriksson A, Johansson W (1997) Soil physical properties of afforested and arable land. Soil Use Manag. 13: 209-217

Messing I, Alriksson A, Johansson W (1997). Soil physical properties of afforested and arable land. Soil Use Manag. 13: 209-217

Montagnini $F$ (2004) Carbon sequestration: an underexploited environmental benefit of agroforestry systems. Agrofor. Syst. 61: 281-295

Moore T, Knowles R (1989) The influence of water table levels on methane and carbon dioxide emissions from peatland soils. Can. J. Soil Sci. 69: 33-38

Moreno G, Obrador JJ, Cubera E, Dupraz C (2005) Fine root distribution in Dehesas of CentralWestern Spain. Plant Soil. 277: 153-162

Mulia R, Dupraz C (2006) Unusual fine root distributions of two deciduous tree species in Southern France: what consequences for modelling of tree root dynamics? Plant Soil 281: 71-85

Nair PKR, Kumar BM, Nair VD (2009) Agroforestry as a strategy for carbon sequestration. J. Plant Nutr. Soil Sci. 172: 10-23

Nair PKR (2011) Methodological challenges in estimating carbon sequestration potential of agroforestry systems. In: Kumar BM, Nair PKR (eds) Carbon Sequestration Potential of Agroforestry Systems. Springer, pp 3-16.

Nkomaula JC (1996) Root distribution of Four-Year-Old Poplar in a Silvo-Arable System. Unpublished MSc Thesis. Cranfield University, Bedfordshire.

Oelbermann M, Voroney RP (2007) Carbon and nitrogen in a temperate agroforestry system: Using stable isotopes as a tool to understand soil dynamics. Ecol. Eng. 29: 342-349

Pandey D (2002). Carbon sequestration in agroforestry systems. Clim. Policy 2: 367-377

Pasturel P (2004). Light and water use in a poplar silvoarable system. Unpublished MSc by Research Thesis, Cranfield University. Bedfordshire.

Peichl M, Thevathasan NV, Gordon AM, Huss J, Abohassan R (2006) Carbon sequestration potentials in temperate tree-based intercropping systems, Southern Ontario, Canada. Agrofor. Syst. 66: 243-257

Pietola L, Alakukku L (2005) Root growth dynamics and biomass input by Nordic annual field crops. Agric. Ecosyst. Environ. 108: 135-144

Post WM, Kwon KC (2000) Soil carbon sequestration and land-use change: processes and potential. Glob. Change Biol. 11: 317-327

R Development Core Team (2011) R: A language and environment for statistical computing.

Recous S, Coppens F, Abiven S, Garnier P, Merckx R (2008) Carbon and Nitrogen Dynamics in Soils: Effects of Residue Quality and Localization. In: Systems for Enhancing 
Management of Agroforestry Systems. Vienna: International Atomic Energy Agency, p. 99.

Richter DD, Markewitz D, Trumbore SE, Wells CG (1999) Rapid accumulation and turnover of soil carbon in a re-establishing forest. Nature. 400: 14-16

Rumpel C., Kögel-Knabner I. \& Bruhn F. (2002) Vertical distribution, age, and chemical composition of organic carbon in two forest soils of different pedogenesis. Org. Geochem. 33: 1131-1142

Schöning I, Kögel-Knabner I (2006) Chemical composition of young and old carbon pools throughout Cambisol and Luvisol profiles under forests. Soil Biol. Biochem.38: 24112424

Seobi T, Anderson SH, Udawatta RP, Gantzer CJ (2005) Influence of Grass and Agroforestry Buffer Strips on Soil Hydraulic Properties for an Albaqualf. Soil Sci. Soc. Am. J. 69: 893

Sharrow SH, Ismail S (2004) Carbon and nitrogen storage in agroforests, tree plantations, and pastures in western Oregon, USA. Agrofor. Syst. 60: 123-130

UNEP (2011) Bridging the Emissions Gap. United Nations Environment Programme (UNEP).

Veen J, Ladd JN, Osmond G (1985) Turnover of carbon and nitrogen through the microbial biomass in a sandy loam and a clay soil incubated with $14 \mathrm{C}$ glucose under different moisture regimes. Soil Biol. Biochem. 17: 747-756.

Vesterdal L, Ritter E (2002) Change in soil organic carbon following afforestation of former arable land. For. Ecol. Manag. 169: 137-147

Zimmermann M, Leifeld J, Schmidt MWI, Smith P, Fuhrer J (2007) Measured soil organic matter fractions can be related to pools in the RothC model. Eur. J. Soil Sci. 58: 658-667 